Article

\title{
Detection and Identification of the First Viruses in Chia (Salvia hispanica)
}

\section{Marcos G. Celli ${ }^{1}$, Maria C. Perotto ${ }^{1,2}$, Julia A. Martino ${ }^{2}$, Ceferino R. Flores ${ }^{3}$,}

Vilma C. Conci ${ }^{1,2, *}$ and Patricia Rodriguez Pardina ${ }^{1}$

1 Instituto de Patología Vegetal (IPAVE - CIAP - INTA) Camino. 60 cuadras Km 5,5, Córdoba, X5020ICA, Argentina; E-Mails: marcoscelli@hotmail.com (M.G.C.); perotto.cecilia@inta.gob.ar (M.C.P); rodriguez.patricia@inta.gob.ar (P.R.P.)

2 Consejo Nacional de Investigaciones Científicas y Técnicas (CONICET), Camino. 60 cuadras Km 5,5, Córdoba, X5020ICA, Argentina; E-Mail: julia22_09@hotmail.com

3 Estación Experimental Agropecuaria Yuto (INTA), Ruta Nacional 34 Km 1286, Yuto, 4518, Jujuy, Argentina; E-Mail: flores.ceferino@inta.gob.ar

* Author to whom correspondence should be addressed; E-Mail: conci.vilma@inta.gob.ar; Tel.: +54-351-497-3636; Fax: +54-351-497-4330.

Received: 17 July 2014; in revised form: 19 August 2014 / Accepted: 20 August 2014 / Published: 19 September 2014

\begin{abstract}
Chia (Salvia hispanica), an herbaceous plant native to Latin America, has become important in the last 20 years due to its beneficial effects on health. Here, we present the first record and identification of two viruses in chia plants. The comparison of the complete nucleotide sequences showed the presence of two viral species with the typical genome organization of bipartite New World begomovirus, identified as Sida mosaic Bolivia virus 2 and Tomato yellow spot virus, according to the ICTV taxonomic criteria for begomovirus classification. DNA-A from Sida mosaic Bolivia virus 2 exhibited 96.1\% nucleotide identity with a Bolivian isolate of Sida micrantha, and Tomato yellow spot virus showed 95.3\% nucleotide identity with an Argentine bean isolate. This is the first report of begomoviruses infecting chia as well as of the occurrence of Sida mosaic Bolivia virus 2 in Argentina.
\end{abstract}

Keywords: begomovirus; chia; geminivirus; Salvia hispanica; virus 


\section{Introduction}

Chia (Salvia hispanica) is an herbaceous plant of the Lamiaceae family, native to mountain areas of South America, from Mexico to Guatemala. Chia, along with corn and bean, was the basis of the diet of indigenous people and was third in economic importance [1]. Chia cultivation was drastically reduced by the Spanish colonizers; however, during the last two decades, the confirmation of its beneficial properties for human health has made chia one of the crops with the highest nutritional profile in Latin America, being commercially produced in Mexico, Bolivia and Argentina [1]. The cultivated area in Argentina was 70,000 ha in 2013 , with a return that far exceeded that of soybean [2,3].

Chia seeds are rich in oil, dietary fibers, protein and mucilage. Its oil accounts for $33 \%$ of its seed weight, with $68 \%$ being $\alpha$-linolenic acid, the highest percentage recorded in oilseeds [4]. Seed consumption has not shown any of the problems associated with other sources of omega-3 fatty acids, such as fishy taste, weight loss in animals or digestive problems [5-7]. Chia contains $25 \%$ dietary fiber ( $10 \%$ soluble fiber of very high molecular weight) and $20 \%$ content of gluten-free proteins, which makes it suitable for people suffering from celiac disease [4].

To date, several viruses naturally infecting the genus Salvia have been reported, such as Cucumber mosaic virus (CMV) in S. uliginosa [8] and S. splendens [9], Broad bean wilt virus 2 in S. officinalis [10], two begomoviruses (Mung bean yellow mosaic virus and Tomato yellow leaf curl virus) in S. splendens [11] and another putative begomovirus, Clerodendron golden mosaic China virus [12].

Up to the present, there has been no information of viruses affecting chia crop. In Argentina, a high percentage of plants with typical symptoms of viral infections, such as mosaic, deformed and stunted leaves and chlorosis, which notably affected crop production, have ben detected in recent crop seasons. The aim of this work was to detect and identify the infections produced by virus in chia plants collected from production areas.

\section{Materials and Methods}

In 2013, samples of chia plants showing leaf deformation, chlorosis and dwarfing (Figure 1) were collected from production fields located in the north of Salta $\left(23^{\circ} 13^{\prime} \mathrm{S}, 64^{\circ} 06^{\prime} \mathrm{W}\right)$.
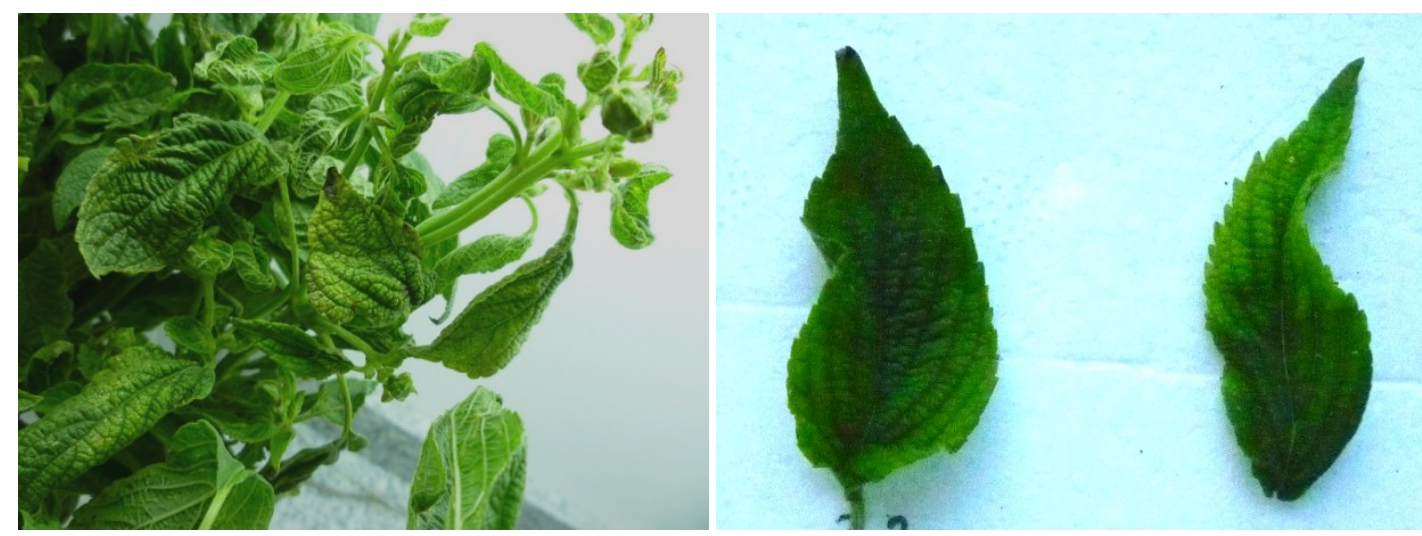

Figure 1. Chia plants showing viral disease symptoms: dwarfism, chlorosis and deformation. 
The symptomatic chia plants were screened for the presence of Alfalfa mosaic virus, Cucumber mosaic virus, Potyvirus genus, Tobacco mosaic virus and Tospovirus group (I, II and III) by double-antibody sandwich enzyme-linked immunosorbent assay (DAS-ELISA) [13] using commercial antisera (BIOREBA SRL Latin America, Mar del Plata, Argentina), according to the manufacturer's instructions. The samples were also tested by PCR using the oligonucleotides PAL1v1978/PAR1c496 [14], which amplify a 1,100-1,300 nt fragment corresponding to the 5'region of the Rep gene, the entire common region and the 5 'end of the $C P$ gene of begomoviruses.

Total DNA from chia plants was extracted using ZR-96 Plant/Seed DNA Kit ${ }^{\mathrm{TM}}$ (ZYMO, Irvine, $\mathrm{CA}$, USA). PCR reactions were prepared in a $25 \mu \mathrm{L}$ volume containing $5 \mathrm{X}$ buffer, $3.5 \mathrm{mM} \mathrm{Mg}_{2} \mathrm{Cl}$, $0.25 \mathrm{mM}$ of dNTP mix, $0.75 \mu \mathrm{M}$ of each primer, 1 unit of Taq DNA polymerase (Promega Corp., Madison, WI, USA) and $1 \mu \mathrm{L}$ of DNA. PCR cycle parameters were as follows: $94{ }^{\circ} \mathrm{C}$ for $2 \mathrm{~min}, 30$ cycles of $94{ }^{\circ} \mathrm{C}$ for $30 \mathrm{~s}, 55{ }^{\circ} \mathrm{C}$ for $90 \mathrm{~s}, 72{ }^{\circ} \mathrm{C}$ for $90 \mathrm{~s}$, and a final extension of $72{ }^{\circ} \mathrm{C}$ for $10 \mathrm{~min}$. PCR products were analyzed by electrophoresis in $1.5 \%$ agarose gels and visualized with UV light after ethidium bromide staining.

Total DNA was subsequently used as template to amplify the putative full-length begomovirus genomes by rolling circle amplification (RCA) with $\Phi 29$ DNA polymerase (Templiphi GE Healthcare, Piscataway, NJ, USA) as previously described [15]. To select an enzyme that could cut at a single site in the genome of begomovirus, generating unit-size molecules, the amplified DNA was digested independently with seven different restriction enzymes (EcoRI, EcoRV, XbaI, PstI, KpnI, HindIII and BamHI). Linearized fragments were cloned in pBluescript $\mathrm{SK}+$ [16] digested with the same restriction enzyme, transformed into Escherichia coli DH5 $\alpha$ and sequenced the Genomics Unit of the Biotechnology Institute-INTA (Argentina).

The nucleotide and deduced amino acid sequences were compared with those of other begomoviruses available in the GenBank [17]. Database searches were carried out using the Blastn algorithm [18]. The viral sequences showing highest identity were selected for the identity percentage analysis using Lasergene 8.0.2 software package (DNASTAR, Inc., Madison, WI, USA).

A phylogenetic analysis of the sequences was performed with Mega 5.2 software [19] using the Neighbor-Joining maximum likelihood method, GTR (general time reversible) model with G+I (invariant sites and distributed range). The bootstrap consensus tree was inferred from 1000 replicates.

\section{Results and Discussion}

None of the tested samples reacted with any of the used antisera. PCR products of the expected size (1250 bp) were obtained for two of the five chia plants analyzed, confirming the presence of a begomovirus infection.

Circular DNA genomes amplified by RCA were linearized with the $X b a \mathrm{I}$ and KpnI restriction enzymes for SM1 and SM2 clones, respectively, and with BamHI for TO1 and TO2 clones. The sequence analysis of clones SM1 (KJ742421) and TO1 (KJ742419) showed the typical genome organization of DNA-A of bipartite New World begomoviruses, with five open reading frames (ORFs), encoding replication-associated protein (Rep), transcriptional activator protein (TrAP), replication enhancer protein (REn), AC4, and coat protein (CP). Clones SM2 (KJ742422) and TO2 
(KJ742420) encoded the movement proteins (MP) and nuclear shuttle proteins (NSP), included in the DNA-B of begomoviruses.

According to the ICTV criteria for differentiation of begomovirus species $(89 \%$ nucleotide identity) [20], the comparison of the sequences obtained in this work and the geminivirus sequences from the database revealed a mixed infection by two different begomoviruses. The clones SM1 and SM2 showed $96.1 \%$ and $93.7 \%$ nt identity for DNA-A and DNA-B, respectively, with the sequences of Sida mosaic Bolivia virus 2 (SiMBoV2, HM585443/HM585444) previously detected infecting plants of Sida micrantha in Bolivia [21], therefore, considering it a new isolate of SiMBoV2.

The clone TO1 showed the highest nucleotide identity $(95.3 \%)$ with DNA-A of an isolate of Tomato yellow spot virus (ToYSV, FJ538207) infecting bean (Phaseolus vulgaris) in Argentina [22], but also presented nucleotide identity above $89 \%$ with three other ToYSV isolates, four isolates of Leonurus mosaic virus (LeMV), and one of Sida micrantha mosaic virus (SimMV), whereas the isolates of Okra mottle virus (OMoV), Sida yellow mosaic virus (SiYMV), Sida mosaic virus (SiMoV) and Sida yellow net virus (SiYNV) showed identity between $80 \%$ and $89 \%$ (Table 1). The clone TO2 had higher identity with DNA-B of two Brazilian ToYSV isolates: 91.2\% with the Leonurus sibiricus isolate (JX513953) [23] and 90.1\% with the Lycopersicon esculentum isolate (DQ336351) [24]. Considering that Leonurus mosaic virus might be a strain of ToYSV [25] and that the two highest identity of DNA-A and DNA-B were obtained from the comparison with two ToYSV isolates, we propose that the isolate described here is ToYSV.

Table 1. Nucleotide identity of the DNA-A sequence of Tomato yellow spot virus isolated from chia (clone TO1).

\begin{tabular}{ccccc}
\hline Virus & Acronym & Origin & GenBank Accession Number & \% of Identity \\
\hline Tomato yellow spot virus & ToYSV & Argentina & FJ538207 & $95.3 \%$ \\
Tomato yellow spot virus & ToYSV & Brazil & JX513952 & $93.9 \%$ \\
Leonurus mosaic virus & LeMV & Brazil & JX863082 & $93.6 \%$ \\
Leonurus mosaic virus & LeMV & Brazil & JX863081 & $93.5 \%$ \\
Leonurus mosaic virus & LeMV & Brazil & JQ429791 & $93.4 \%$ \\
Leonurus mosaic virus & LeMV & Paraguay & KC683374 & $91.6 \%$ \\
Tomato yellow spot virus & ToYSV & Brazil & KC706628 & $89.9 \%$ \\
Tomato yellow spot virus & ToYSV & Brazil & DQ336350/NC_007726 & $89.8 \%$ \\
Sida micrantha mosaic virus & SimMV & Brazil & AJ557450 & $89.2 \%$ \\
Sida mottle virus & SiMoV & Brazil & AY090555/NC_004637 & $88.9 \%$ \\
Sida micrantha mosaic virus & SimMV & Brazil & FN557522 & $88.6 \%$ \\
Sida mottle virus & SiMoV & Brazil & JX871378 & $88.1 \%$ \\
Sida mottle virus & SiMoV & Brazil & JX871377 & $88.0 \%$ \\
Okra mottle virus & OMoV & Brazil & EU914817 & $87.1 \%$ \\
Okra mottle virus & OMoV & Brazil & EU914819 & $87.1 \%$ \\
Okra mottle virus & OMoV & Brazil & FJ686695 & $87.0 \%$ \\
Sida yellow net virus & SiYNV & Brazil & JX871376 & $86.6 \%$ \\
Sida yellow mosaic virus & SiYMV & Brazil & JX871369 & $83.1 \%$ \\
Sida yellow mosaic virus & SiYMV & Brazil & AY090558/NC_004639 & $83.1 \%$ \\
\hline
\end{tabular}


The phylogenetic tree (Figure 2) was constructed using complete nucleotide sequences of DNA-A and DNA-B of both isolates, sequences published in GenBank that showed more than $80 \%$ identity, and those of begomoviruses reported in Argentina. The genome sequences of DNA-A and DNA-B of SiMBoV2 obtained in this work grouped on a monophyletic branch, with $100 \%$ bootstrap confidence, with the SiMBoV2 sequence from Bolivia, confirming that these isolates are closely related. The phylogenetic relationship between the DNA-A sequence of ToYSV from Argentina and other begomoviruses (Figure 2) showed that the isolate obtained from the Argentine samples of chia clustered with other sequences of ToYSV and LeMV, but was more closely related to the Argentine isolate from ToYSV (FJ538207), with 99\% bootstrap confidence value.
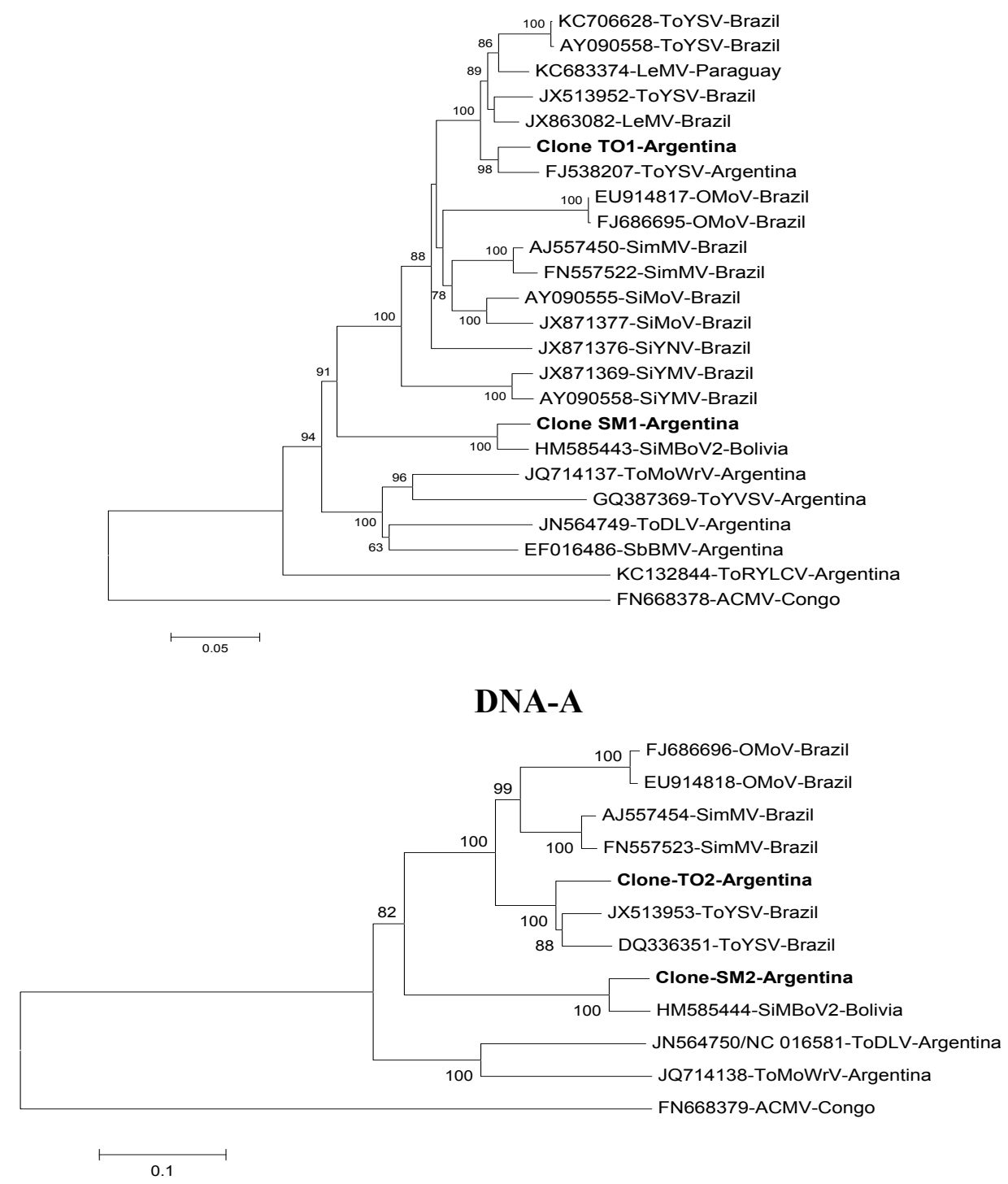

DNA-B

Figure 2. Neighbor-joining trees showing the phylogenetic relationship between DNA-A and DNA-B of the isolates detected in this study and other begomoviruses and from the international database GenBank [17] and using African cassava mosaic virus (ACMV) as an outgroup. Numbers next to the branch points indicate bootstrap values (1,000 replicates) above 50\% (0.5). SbBMV, ToYVSV, ToDLV, SPLCV, ToMoWrV, ToRYLCV, ToDLV. 


\section{Conclusions}

Here, we demonstrate the presence of two bipartite begomovirus infecting Salvia hispanica associated with severe disease symptoms in chia. Possibly, it was transmitted by whiteflies and the presence of these begomovirus in Argentina must be considered as a threat to the chia crop, since whitefly populations are present in the north-western Argentina [26]. This information is relevant for the implementation of control strategies to reduce disease damage. Given the increasing economic importance of this crop as agricultural product in the country [3], more studies are necessary to estimate the damage caused by SiMBo2 and ToYSV.

To the best of our knowledge, this is the first report of viral infection in chia plants, as well as of the presence of Sida mosaic Bolivia virus 2 in Argentina. The latter was previously reported to infect the weed $S$. micrantha [21], and the present results are the first references to the virus infecting a cultivated species.

\section{Acknowledgments}

This study was carried out at IPAVE-CIAP-INTA and was partially supported by INTA and CONICET.

\section{Author Contributions}

V.C.C. and P.R.P designed the study; M.G.C, M.C.P and J.A.M. conducted experiments; C.R.F. identified and collection of symptomatic plants. All authors contributed to the analysis of the results and writing the paper.

\section{Conflicts of Interest}

The authors declare no conflict of interest.

\section{References}

1. Ayerza, R.; Wayne, C. Chía, redescubriendo un olvidado alimento de los Aztecas, $1^{\text {st }}$ ed.; Del Nuevo Extremo: Buenos Aires, Argentina, 2006; p. 232.

2. Lobo Zavalía, R.; Alcocer, M.G.; Fuentes, F.J.; Rodriguez, W.A.; Morandini, M.; Devani, M.R. Desarrollo del cultivo de chía en Tucumán. República Argentina. Av. Agroind. 2011, 32, 27-30.

3. La Gaceta. Economía-En el NOA se perdió entre el $70 \%$ y el $80 \%$ de la producción de chía, debido a la sequía. 2013. Available online: http://www.lagaceta.com.ar (accessed on 16 August 2013).

4. Ayerza, R. Seed composition of two chía (Salvia hispanica L.) genotypes which differ in seed color. Emir. J. Food Agric. 2013, 25, 495-500.

5. Ayerza, R.; Coates, W. Dietary levels of chia: Influence on yolk cholesterol, lipid content and fatty acid composition, for two strains of hens. Poult. Sci. 2000, 78, 724-739.

6. Ayerza, R.; Coates, W. The omega-3 enriched eggs: The influence of dietary linolenic fatty acid source combination on egg production and composition. Can. J. Anim. Sci. 2001, 81, 355-362. 
7. Ayerza, R.; Coates, W.; Lauria, M. Chia seed (Salvia hispanica L.) as an $\omega-3$ fatty acid source for broilers: Influence on fatty acid composition, cholesterol and fat content of white and dark meat, growth performance and sensory characteristics. Poult. Sci. 2002, 81, 826-837.

8. Holcomb, G.E.; Valverde, R.A. Natural Infection of Salvia uliginosa with Cucumber mosaic cucumovirus. HortScience 1998, 33, 1215-1216.

9. Ali, S.; Khan, A.A.; Afreen, B.; Sharma, R.; Jahan, T.; Naqvi, Q.A. Natural occurrence of Cucumber mosaic virus associated with mottling and mosaic disease on Salvia splendens, a new record from India. Australas. Plant Dis. Notes 2008, 3, 118-120.

10. Mumford, R.A.; Jarvis, B.; Harju, V.; Boonham, N.; Skelton, A. The first report of Broad bean wilt virus 2 in the UK: findings in foxglove and salvia. Plant Pathol. 2006, 55, 819.

11. Ara, M.R.; Masud, M.M.H.; Akanda, A.M. Detection of plant viruses in some ornamental plants that act as alternate hosts. Agriculturists 2012, 10, 46-54.

12. Valverde, R.A.; Singh, R.; Sabanadzovic, S. Detection and identification of Clerodendron golden mosaic China virus in Salvia splendens. Eur. J. Plant Pathol. 2012, 133, 499-503.

13. Clark, M.F.; Adams, A.N. Characteristics of the microplate method of enzyme-linked immunosorbent assay for the detection of plant viruses. J. Gen. Virol. 1977, 34, 475-483.

14. Rojas, M.R.; Gilbertson, R.L.; Russell, D.R.; Maxwell, D.P. Use of degenerate primers in the polymerase chain reaction to detect whitefly-transmitted geminiviruses. Plant Dis. 1993, 77, 340-347.

15. Inoue-Nagata, A.K.; Albuquerque, L.C.; Rocha, W.B.; Nagata, T. A simple method for cloning the complete begomovirus genome using the bacteriophage phi 29 DNA polymerase. J. Virol. Method 2004, 116, 209-211.

16. Maniatis, T.; Fritsch, E.F.; Sambrook, J. Molecular Cloning: A Laboratory Manual; Cold Spring Harbor Laboratory Press: Cold Spring Harbor, New York, NY, USA, 1982; p. 1626.

17. GenBank, National Center for Biotechnology Information - NCBI. Available online: http://www.ncbi.nlm.nih.gov (accessed on 15 June 2014).

18. Altschul, S.F.; Gish, W.; Miller, W.; Myers, E.W.; Lipman, D.J. Basic local alignment search tool. J. Mol. Biol. 1990, 215, 403-410.

19. Tamura, K.; Peterson, D.; Peterson, N.; Stecher, G.; Nei, M.; Kumar, S. MEGA5: Molecular Evolutionary Genetics Analysis using Maximum Likelihood, Evolutionary Distance, and Maximum Parsimony Methods. Mol. Biol. Evol. 2011, 28, 2731-2739.

20. Brown, J.K.; Fauquet, C.M.; Briddon, R.W.; Zerbini, M.; Moriones, E.; Navas Castillo, J. Geminiviridae. In Virus taxonomy. Ninth Report of the International Committee on Taxonomy of Viruses; King, A.M.Q., Adams, M.J., Carstens, E.B., Lefkowitz, E.J., Eds.; Elsevier Academic Press: London, UK, 2012; pp. 351-373.

21. Wyant, P.S.; Gotthardt, D.; Schäfer, B.; Krenz, B.; Jeske, H. The genomes of four novel begomoviruses and a new Sida micrantha mosaic virus strain from Bolivian weeds. Arch. Virol. 2011, 156, 347-352.

22. Rodríguez Pardina, P.E.; Hanada, K.; Laguna, I.G.; Zerbini, F.M.; Ducasse, D.A. Molecular characterization and relative incidence of bean- and soybean-infecting begomoviruses in northwestern Argentina. Ann. Appl. Biol. 2011, 158, 69-78.

23. Barbosa, J.C.; Eckstein, B.; Bergamin Filho, A.; Rezende, J.A.M.; Dallagnol, L.J. First Report of Tomato yellow spot virus Infecting Leonurus sibiricus in Brazil. Plant Dis. 2013, 97, 289. 
24. Calegario, R.F.; Ferreira, S.S.; Andrade, E.C.; Zerbini, F.M. Characterization of Tomato yellow spot virus, a novel tomato-infecting begomovirus in Brazil. Pesquisa Agropecuária Brasileira 2007, 42, 1335-1343.

25. Fernandes, N.A.N.; Boiteux, L.S.; Fonseca, M.E.N.; Segnana, L.G.; Kitajima, E.W. Report of Tomato yellow spot virus infecting Leonurus sibiricus in Paraguay and within tomato fields in Brazil. Plant Dis. 2013, 97, 289.

26. Alemandri, V.; Rodriguez Pardina, P.; Izaurralde, J.; García Medina, S.; Argüello Caro, E.; Mattio, M.F.; Dumón, A.; Rodriguez, S.M.; Truol, G. Incidence of begomoviruses and climatic characterisation of Bemisia tabaci-geminivirus complex in soybean and bean in Argentina. Agriscientia 2012, 29, 31-39.

(C) 2014 by the authors; licensee MDPI, Basel, Switzerland. This article is an open access article distributed under the terms and conditions of the Creative Commons Attribution license (http://creativecommons.org/licenses/by/3.0/). 